\title{
МИГРАЦИЯ И РИСКИ ВИЧ-ИНФЕКЦИИ: ЖЕНЩИНЫ - ВЫХОДЦЫ ИЗ СРЕДНЕЙ АЗИИ В РОССИЙСКОЙ ФЕДЕРАЦИИ *
}

\author{
ВИКТОР АГАДЖАНЯН, НАТАЛЬЯ ЗОТОВА
}

\begin{abstract}
Взаимосвязь между мигращией и ВИЧ-инфекичей - предмет растущего числа международных исследований. Демонстрируя повышенные риски ВИЧ среди мигрантов, исследования выявляют и гендерную специффику этих рисков. В настоящей статье используются даннье опроса и глубинных интервью, проведенных в трех российских городах среди работающих женщин из трех среднеазиатских стран - Киргизии, Таджикистана и Узбекистана, а также работающих местных женщин для анализа рисков и взглядов, связанных с ВИЧ. В частности, анализируются рискованные половые отношения, безопасные сексуальные практики между постоянными партнерами, опыт тестирования на ВИЧ и пользование услугами в области полового $u$ репродуктивного здоровья; сравниваются местные женщины с женщинами-мигрантами, а также женщины-мигранты из разных стран. Результаты показывают, что вероятность рискованных сексуальных связей в ичелом ниже среди мигрантов, чем среди местных женщин. $B$ тоже время мигранты менее способны договориться о безопасных сексуальных практиках $c$ постоянными партнерами. Вероятность тестирования на ВИЧ ниже среди мигрантов, их доступ к услугам в области полового и репродуктивного здоровья более ограничен по сравнению с местными женщинами. Однако анализ также показывает значительные различия между мигрантами из трех стран. Эти различия нуждаются в дальнейшем изучении.
\end{abstract}

Ключевые слова: миграция, гендер, ВИЧ/СПИД, сексуальные риски.

\section{МИГРАЦИЯ, ГЕНДЕР И ВИЧ}

Несмотря на меры по предотвращению развития эпидемии ВИЧ в Российской Федерации, уровень инфицированности продолжает расти. Количество выявленных носителей ВИЧ в промежутке между 2005 и 2010 г. удвоилось ${ }^{1}$. Хотя основную долю инфицированных составляют мужчины, в частности потребители инъекционных наркотиков, доля женщин среди инфицированных увеличивается: в 2010 г. она составила 35\%, а в когорте 15-24 лет число инфицированных женщин превышает число мужчин [UNAIDS 2012].

ВИКТОР СЕРГЕЕВИЧ АГАДЖАНЯН, УНИВЕРСИТЕТ ШТАТА АРИЗОНА. США. E-MAIL: agadjanian@asu.edu. НАТАЛЬЯ АЛЕКСАНДРОВНА ЗОТОВА, ИНСТИТУТ ЭТНОЛОГИИ И АНТРОПОЛОГИИ РАН. РОССИЯ.

СТАТЬЯ ПОСТУПИЛА В РЕДАКЦИЮ В МАЕ 2014 Г.

* СТАТЬЯ ПОДГОТОВЛЕНА В РАМКАХ ИССЛЕДОВАНИЯ «СЕКСУАЛЬНЫЕ И РЕПРОДУКТИВНЫЕ РИСКИ ЖЕНЩИНМИГРАНТОВ ИЗ ЦЕНТРАЛЬНОЙ АЗИИ В КОНТЕКСТЕ ЭПИДЕМИИ ВИЧ», ВЫПОЛНЕННОГО ПРИ ПОДДЕРЖКЕ РОССИЙСКОГО ФОНДА ФУНДАМЕНТАЛЬНЫХ ИССЛЕДОВАНИЙ И НАЦИОНАЛЬНОГО ИНСТИТУТ ЗДОРОВЬЯ США.

1 Письмо Роспотребнадзора от 23.03.2011г. № 01/3240-1-32 «О мерах по противодействию распространения эпидемии ВИЧ-инфекции в Российской Федерации и повышению их эффективности». 
Мигранты в России считаются группой высокого риска ВИЧ-инфицирования [Amirkhanian et al. 2011; Демоскоп Weekly 2009], что совпадает с выводами исследований и значительного числа публикаций по повышенным рискам ВИЧ, связанным с миграцией [Agadjanian, Avogo 2008; Agadjanian, Arnaldo, Cau 2011; Brockerhoff, Biddlecom 1999; Decosas et al. 1995; Lurie 2006; Sevoyan, Agadjanian 2010; Weine, Kashuba 2012; Yang 2004]. Риски мигрантов также усугубляются их ограниченным доступом к медицинским услугам в целом и к услугам, связанным с ВИЧтестированием, консультированием и лечением, в частности.

Подавляющее большинство мигрантов приезжают в РФ из стран, которые входили в состав Советского Союза; при этом значительную и постоянно растущую долю составляют выходцы из трех государств Средней Азии: Киргизии, Таджикистана и Узбекистана. По данным Федеральной миграционной службы (ФМС) на октябрь 2014 г. на территории РФ находилось 450 тыс. граждан Киргизии, 731 тыс. граждан Таджикистана и 2174 тыс. граждан Узбекистана в возрасте 18-59 лет [ФМС 2014].

Хотя у коренных народов этих трёх стран много общих черт, особенно в сравнении с населением России, между ними существуют важные этнокультурные различия. Так, киргизы и узбеки говорят на похожих тюркских языках, в то время как таджикский относится к иранской группе. Узбеки и таджики представляют оседлое население Средней Азии; киргизы с древности вели кочевой образ жизни и процессы массового оседания на земле у них начались сравнительно недавно по историческим меркам - с конца XIX века. Все три изучаемые этнические группы являются мусульманскими, однако влияние ислама более сильно среди таджиков и узбеков. Это также определяет различное положение женщин в семье и обществе - киргизки пользуются большей свободой в повседневной жизни, они более мобильны и активны по сравнению с женщинами традиционно оседлых народов Средней Азии. Некоторые из отмеченных различий могут повлиять на сексуальное поведение и риски выходцев из трех стран.

Подавляющее большинство выходцев из Средней Азии прибывают в Россию как временные трудовые мигранты. Крупнейшим центром притяжения мигрантов выступают Москва и Московская область, но мигранты направляются и в другие крупные города РФ.

Первоначально трудовая миграция из стран Средней Азии была практически исключительно мужской, однако лавинообразный рост числа мигрантов-мужчин повлек за собой выезд на заработки в чужую страну и женщин, которые в настоящее время стали заметной частью миграционного потока. Так, по данным ФМС 2014 г,, среди всех находящихся в России граждан Киргизии в возрасте 18-59 лет женщины составляли $38 \%$, среди граждан Таджикистана - 19\%, среди граждан Узбекистана - 17\% [ФМС 2014]. Многие мигранты, как мужчины, так и женщины, являются в той или иной степени недокументированными (например, у них может отсутствовать регистрация по месту жительства и / или разрешение на работу), вследствие этого они часто подвергаются эксплуатации, испытывают давление и угрозы со стороны работодателей 
и сотрудников правоохранительных органов. Внешность среднеазиатских мигрантов, выделяющая их среди жителей РФ, религиозная принадлежность (практически все мусульмане) и зачастую плохое владение русским языком также усугубляют их тяжелое правовое и экономическое положение [Menjívar, Zotova, Agadjanian 2012].

В то время как исследования, связанные с рисками ВИЧ, сконцентрированы в основном на мужчинах-мигрантах, женщины-мигранты (быстро растущий сегмент среди общего числа мигрантов в России) до настоящего времени изучались мало. Между тем можно предположить, что, по сравнению с мужчинами, женщины-мигранты более подвержены этим рискам в силу гендерного неравенства, которое усиливает социальные и экономические проблемы, связанные с их правовым статусом [Агаджанян, Зотова 2011; Weine et al. 2013; Zhussupov et al. 2014]. Гендерное неравенство может также вести к повышенному риску ВИЧ и других инфекций, передающихся половым путём (ИППП), и в то же время ещё более затруднять доступ женщин-мигрантов к медицинским услугам в сфере сексуального и репродуктивного здоровья, включая тестирование на ВИЧ/ИППП, консультирование и лечение. Учитывая быстрый рост числа ВИЧинфицированных в РФ, рост доли женщин среди инфицированных, с одной стороны, и маргинализацию женщин-мигрантов в российском обществе, с другой, женщинымигранты могут быть в большей степени подвержены риску ВИЧ-инфекции, чем другие группы населения. Некоторые исследования, проведенные в разных регионах мира, демонстрируют, что склонность женщин-мигрантов к более рискованному сексуальному поведению и подверженность рискам заражения ВИЧ/ИППП среди женщин-мигрантов может быть даже выше, чем у мигрантов-мужчин [Bandyopadhyay, Thomas 2002; Wang et al. 2007; Weine et al. 2013; Yang, Хia 2006, 2008]. Эти исследования также указывают на тесную связь между доступом женщин к медицинским услугам и специалистам, в частности, в репродуктивной и сексуальной сферах, и снижением рисков ВИЧ/ИППП [Агаджанян, Зотова 2011; Askew, Berer 2003; Lindegren 2012].

Для получения разрешения на работу и оформления многих других документов (разрешение на временное проживание, вид на жительство) мигрантам необходимо пройти медицинское освидетельствование, включающее тест на ВИЧ, другие ИППП, гепатит $\mathrm{C}$ и другие заболевания. Стоимость полного освидетельствования достаточно высока. Кроме того, выявленная ВИЧ-инфекция служит основанием для депортации из Р $\Phi^{2}$. В силу перечисленных причин мигранты мало склонны тестироваться на ВИЧ. Как следствие, официальные источники указывают на крайне малый и недостаточный уровень обследования мигрантов на ВИЧ [Роспотребнадзор 2011]. Не случайно в совместной программе по противодействию ВИЧ и другим инфекционным заболеваниям в СНГ, запущенной в июне 2013 г. (РФ совместно с ЮНЭЙДС), мигранты

\footnotetext{
${ }^{2}$ Федеральный закон от 30.03.1995 N 38-Ф3 (ред. от 28.12.2013, с изм. от 04.06.2014) "О предупреждении распространения в Российской Федерации заболевания, вызываемого вирусом иммунодефицита человека (ВИЧ-инфекции)"

Постановление Правительства РФ от 02.04.2003 №188 (ред. от 04.09.2012) “О перечне инфекционных заболеваний, представляющих опасность для окружающих и являющихся основанием для отказа в выдаче либо аннулирования разрешения на временное проживание иностранным гражданам и лицам без гражданства, или вида на жительство, или разрешения на работу в Российской Федерации”
} 
были названы группой особенно высокого риска распространения ВИЧ-инфекции [UNAIDS 2013].

Даже проходя тестирование, мигранты не склонны проходить консультирование по поводу ВИЧ. Иностранные граждане, у которых выявлен ВИЧ-положительный статус, не могут получать бесплатное антиретровирусное лечение (АРВ-терапия) и медикаменты, которые препятствуют передаче инфекции от ВИЧ+ беременной к плоду, это лечение предоставляется бесплатно только для граждан России. В силу очень высокой стоимости лекарственных препаратов АРВ-терапия недоступна для большинства мигрантов [Демоскоп Weekly 2009].

Ограниченный доступ женщин-мигрантов к тестированию на ВИЧ, консультированию и лечению следует рассматривать в контексте их практически полного исключения из сферы услуг здравоохранения в области репродуктивного и сексуального здоровья в России. Мигранты не могут получить полис обязательного медицинского страхования (ОМС), который позволяет бесплатно посещать государственные поликлиники и другие учреждения сферы здравоохранения; также подавляющее большинство мигрантов не могут позволить себе купить полис добровольного медицинского страхования (ДМС), чтобы пользоваться услугами страховой медицины. В случае необходимости мигранты предпочитают платить непосредственно врачам, однако эти затраты также тяжелы для них [Rocheva, Peshkova 2013]. Таким образом, как и в других странах [Bravo 2003; Chavez 2012; Schoevers et al. 2010], ограниченный доступ к медицинским услугам усиливает уязвимость женщинмигрантов в России.

\section{ТЕОРЕТИЧЕСКАЯ МОДЕЛЬ}

В свете данных международных исследований о природе гендерно обусловленных рисков ВИЧ-инфицирования и уязвимости женщин-мигрантов в России, связанной с многими факторами, в нашем исследовании мы ставили цель изучить, как характеристики женщин-мигрантов из Средней Азии и особенности их поведения могут усилить их риски заболевания ВИЧ. В нашем исследовании женщины-мигранты сравниваются с контрольной группой местных женщин, а также проводится сравнение между этническими группами женщин-мигрантов ${ }^{3}$. Мы предполагали, что, в силу религиозных и этнокультурных характеристик женщин из Средней Азии, они менее склонны к рискованному сексуальному поведению, чем женщины-немигранты, но в то же время особенности и динамика брачных отношений ограничивают их возможности

\footnotetext{
${ }^{3}$ Мы используем термин “мигрант” для обозначения людей, которые приехали в РФ из одной из трех стран Средней Азии в любое время после получения этими странами независимости в 1991 г., вне зависимости от первоначальных целей их приезда, длительности пребывания в России и их правового статуса. В группу местных женщин мы включили урожденных россиянок. При этом в группу местных также входят женщины, которые могли проживать ранее в каком-либо месте в РФ до того, как переехали в тот город, в котором с ними было проведено интервью. Этих женщин в нашем исследовании мы не рассматриваем как мигрантов.
} 
контролировать риски, которые могут возникать в отношениях с постоянными партнерами, по сравнению с местными женщинами. Одновременно мы ожидали, что обнаружим значительные вариации среди женщин-мигрантов по этнокультурным характеристикам, социально-экономическому и правовому статусу.

\section{ДАННЫЕ}

Сбор данных проводили с октября 2012 по март 2013 г. В рамках исследования собрали три взаимодополняющих типа данных: 1) анкетирование женщин с использованием полностью структурированной анкеты; 2) полуструктурированные глубинные интервью с частью респондентов анкеты; 3) экспертные интервью с работниками сферы здравоохранения. Все данные были получены в двух основных местах проведения исследования - Москве и Новосибирске. Для более тщательной проверки методов и инструментов исследования и увеличения разнообразия изучаемых групп дополнительные данные были собраны в третьем городе - Екатеринбурге.

Выборка включала представительниц трех этнических мигрантских групп киргизок, узбечек и таджичек, а также контрольную группу немигрантов. Поскольку большое число женщин-мигрантов работают в сфере общественного питания (в основном, официантки и уборщицы), в небольших магазинах (продавщицы, кассиры, мерчендайзеры и уборщицы) и на продуктовых и вещевых рынках (владелицы «точек» и/или продавщицы), мы выбрали для исследования женщин в этих сферах занятости. Выборка не включала женщин, занятых в сфере коммерческого секса, которые подвержены высокому риску ВИЧ-инфицирования [Weine et al. 2013], а по своим представлениям о рисках и связанным с этими рисками поведением сильно отличаются от остальных женщин. Мы также не включили в исследование женщин, занятых в сфере ухода (за детьми, пожилыми и больными людьми), поскольку средний возраст таких женщин обычно более высокий, и следовательно, они уже вышли из возраста пика сексуальной активности, для которого характерны повышенные риски ВИЧ/ИППП.

Для поиска и отбора респонденток, занятых в сфере общепита и формальной торговли (магазины), был использован метод вероятностной выборки «время-место» (time-location) [Agadjanian, Zotova 2012]. Применялась трехступенчатая процедура. На первом этапе территория каждого города была поделена на квадраты площадью 1 км². Затем список квадратов был отсортирован случайным образом, в выбранных квадратах был проведен полный натурный обход, в процессе которого отмечались на карте и составлялись списки всех заведений общепита и магазинов. После этого списки заведений были отсортированы случайным образом. На третьем этапе в выбранных заведениях интервьюеры осуществляли поиск респонденток в возрасте 18-40 лет, представляющих три этнические группы женщин (киргизки, таджички и узбечки) и контрольную группу местных женщин. Интервьюеры посещали выбранные заведения примерно в одно и то же время суток, если в одном заведении было обнаружено несколько подходящих женщин, одну из них отбирали для проведения интервью случайным образом. 
Для поиска респонденток на рынках сначала была осуществлена случайная выборка рынков, затем рынки были закреплены за той или иной этнической группой. Это было сделано для того, чтобы интервьюеры, работающие с разными группами, не мешали друг другу. На выбранных рынках использовали пошаговый алгоритм поиска; если заданное число респонденток определенной этнической группы не было обнаружено на том или ином рынке, добор респонденток осуществляли на случайно выбранных дополнительных рынках.

В результате каждая треть выборки в Москве и Новосибирске была сделана среди женщин, работающих в одном из трех мест - предприятиях общепита, магазинах и на рынках. В Екатеринбурге, дополнительном городе, в выборку были включены только женщины, занятые на рынках. В каждом из трех городов число опрошенных женщин равномерно распределялось между четырьмя этнокультурными группами. Распределение опрошенных женщин представлено в таблицах 1a и $1 \mathrm{~b}$.

Таблица 1а. Число опрошенных респондентов

\begin{tabular}{|c|c|c|c|c|c|}
\hline \multirow{2}{*}{ Город/сектор занятости } & \multicolumn{4}{|c|}{ Этническая группа } & \multirow{2}{*}{ Всего } \\
\hline & киргизки & таджички & узбечки & местные & \\
\hline Москва & 137 & 139 & 140 & 148 & 564 \\
\hline Рынки & 45 & 46 & 48 & 48 & 187 \\
\hline Магазины & 46 & 48 & 47 & 50 & 191 \\
\hline Предприятия общепита & 46 & 45 & 45 & 50 & 186 \\
\hline Новосибирск & 72 & 72 & 72 & 72 & 288 \\
\hline Рынки & 24 & 24 & 24 & 24 & 96 \\
\hline Магазины & 24 & 24 & 24 & 24 & 96 \\
\hline Предприятия общепита & 24 & 24 & 24 & 24 & 96 \\
\hline Екатеринбург & 22 & 21 & 24 & 22 & 89 \\
\hline Рынки & 22 & 21 & 24 & 22 & 89 \\
\hline Всего & 231 & 232 & 236 & 242 & 941 \\
\hline
\end{tabular}

Таблица 1b. Опрошенные респонденты, \%

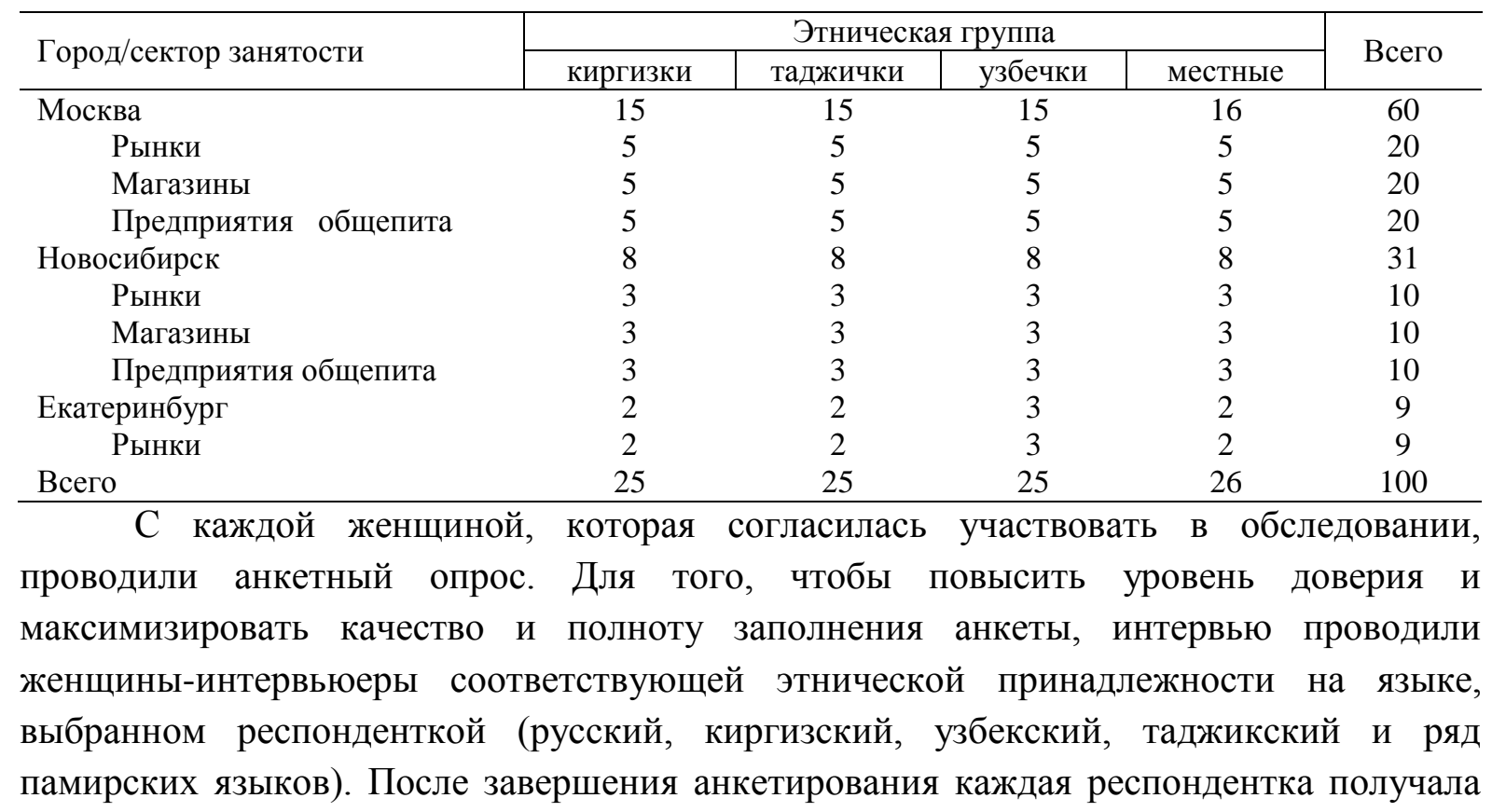


вознаграждение за участие в размере 200 рублей. Для исследования была разработана анкета, состоящая из 25 страниц, в которой содержались вопросы, связанные с этнокультурными и социально-экономическими характеристиками респонденток, миграционной историей, правовым статусом и опытом жизни в России, сексуальным поведением и сексуальными партнерами, восприятием рисков ВИЧ/ИППП и действиями, которые женщины предпринимают для снижения этих рисков, опытом сдачи анализов на ВИЧ/ИППП, симптомами, которые могут быть связаны с ИППП, а также другими темами.

Социально-демографические характеристики респонденток представлены в таблице 2. Как видно из этой таблицы, средний возраст опрошенных респонденток во всех четырех этнокультурных группах примерно одинаков и составляет около 30 лет. Свыше двух третей респонденток имеют постоянного партнера (состоят в зарегистрированном или незарегистрированном браке, совместно проживают или не проживают вместе). Почти треть респонденток имеют высшее или незаконченное высшее образование, однако уровень образования значительно различается между группами: среди киргизок отмечен самый высокий уровень образования, а среди узбечек - самый низкий. Также в группе киргизок отмечен самый высокий уровень доходов по сравнению с двумя другими группами женщин-мигранток; интересно, что средний месячный доход киргизок в Новосибирске и Екатеринбурге даже немного превышает уровень доходов местных женщин. Однако в Москве доходы местных женщин значительно выше доходов женщин-мигранток. В то же время киргизские женщины проживают в самых стесненных жилищных условиях, в одной комнате с ними в среднем ночуют ещё 4 человека, а в Москве ещё 5. Жилищные условия местных женщин наиболее благоприятные, с ними вместе проживает самое малое число людей. Как и следовало ожидать, местные женщины, по сравнению с уроженками Средней Азии, проживали намного более длительное время в тех городах, где с ними было проведено интервью. Почти три четверти респонденток имеют хотя бы одного близкого родственника, проживающего в том же городе, но не в одной квартире с ними. Интересно, что число таких женщин особенно велико среди таджичек, значительно превышая аналогичный показатель даже для местных женщин. Для мигранток среднее число лет, которое они прожили в России, в основном совпадало с временем, которое они прожили в том городе, где было проведено интервью, что указывает на низкий уровень мобильности женщин-мигранток в пределах России ${ }^{4}$. Для таджичек длительность непрерывного проживания в России значительно больше аналогичных показателей как для киргизок, так и для узбечек. Доля женщин, имеющих российское гражданство, значительно выше среди киргизок, что вероятно объясняется облегченной процедурой получения гражданства РФ для граждан Киргизстана, установленной еще в 1997 г. ${ }^{5}$

\footnotetext{
${ }^{4}$ В анкете содержались подробные вопросы о миграционной истории, включая год и месяц долгосрочных переездов (сроком свыше 6 месяцев).

${ }^{5}$ Федеральный закон от 26.05.1997 № 84-Ф3 «О ратификации Соглашения между Российской Федерацией и Киргизской Республикой об упрощенном порядке приобретения гражданства гражданами Российской Федерации, прибывающими для постоянного проживания в Киргизскую Республику, гражданами 
Таблица 2. Социально-демографические характеристики

\begin{tabular}{|c|c|c|c|c|c|}
\hline \multirow{2}{*}{ Город } & \multicolumn{4}{|c|}{ Этническая группа } & \multirow{2}{*}{ Всего } \\
\hline & киргизки & таджички & узбечки & местные & \\
\hline \multicolumn{6}{|l|}{ Средний возраст } \\
\hline Всего & 29 & 30 & 31 & 30 & 30 \\
\hline Москва & 29 & 31 & 32 & 30 & 30 \\
\hline Новосибирск и Екатеринбург & 29 & 29 & 29 & 30 & 29 \\
\hline \multicolumn{6}{|c|}{ Имеют постоянного партнера, официальный брак и незарегистрированные отношения, \% } \\
\hline Всего & 63 & 71 & 71 & 70 & 69 \\
\hline Москва & 64 & 75 & 73 & 66 & 69 \\
\hline Новосибирск и Екатеринбург & 61 & 64 & 68 & 76 & 67 \\
\hline \multicolumn{6}{|c|}{ Высшее и незаконченное высшее образование, \% } \\
\hline Всего & 46 & 22 & 14 & 39 & 31 \\
\hline Москва & 53 & 23 & 13 & 39 & 32 \\
\hline Новосибирск и Екатеринбург & 37 & 22 & 17 & 40 & 29 \\
\hline \multicolumn{6}{|l|}{ Месячный доход (средний), тыс. руб. } \\
\hline Всего & 24 & 18 & 18 & 23 & 20 \\
\hline Москва & 25 & 20 & 18 & 30 & 22 \\
\hline Новосибирск и Екатеринбург & 20 & 15 & 17 & 16 & 16 \\
\hline \multicolumn{6}{|c|}{ Среднее число людей, которые ночуют в одной комнате с респонденткой } \\
\hline Всего & 3,9 & 2,8 & 2,8 & 1,1 & 2,6 \\
\hline Москва & 5,0 & 3,4 & 3,5 & 1,1 & 3,2 \\
\hline Новосибирск и Екатеринбург & 2,2 & 1,9 & 1,8 & 1,1 & 1,8 \\
\hline \multicolumn{6}{|c|}{ Среднее число лет, которое респондентка непрерывно проживает в городе } \\
\hline Всего & 2,8 & 3,8 & 2,9 & 7,3 & 4,2 \\
\hline Москва & 2,2 & 3,6 & 2,4 & 6,5 & 3,8 \\
\hline Новосибирск и Екатеринбург & 3,5 & 4,1 & 3,5 & 8,5 & 4,9 \\
\hline \multicolumn{6}{|c|}{$\begin{array}{l}\text { Имеет хотя бы одного близкого взрослого родственника, живущего в том же городе (но не в одной } \\
\text { квартире с респонденткой), \% }\end{array}$} \\
\hline Всего & 69 & 92 & 60 & 76 & 74 \\
\hline Москва & 70 & 97 & 59 & 70 & 74 \\
\hline Новосибирск и Екатеринбург & 68 & 84 & 61 & 84 & 74 \\
\hline \multicolumn{6}{|c|}{ Среднее число лет, которое респондентка непрерывно проживает в России (только для мигрантов) } \\
\hline Всего & 3,0 & 3,9 & 3,0 & постоянно & 3,3 \\
\hline Москва & 2,4 & 3,6 & 2,5 & “ & 2,9 \\
\hline Новосибирск и Екатеринбург & 3,9 & 4,4 & 3,7 & “ & 4,0 \\
\hline \multicolumn{6}{|c|}{ Имеют гражданство РФ (только для мигрантов), \% } \\
\hline Всего & 42 & 19 & 11 & & 24 \\
\hline Москва & 34 & 6 & 3 & & 14 \\
\hline Новосибирск и Екатеринбург & 54 & 38 & 22 & & 38 \\
\hline
\end{tabular}

Kачественные данные в исследовании были получены путем проведения глубинных интервью. В двух основных городах проведения исследования, Москве и Новосибирске, были отобраны и проинтервьюированы 40 респонденток, по 20 в каждом городе (15 женщин-мигранток, по 5 в каждой этнической группе, и по 5 местных женщин). Полуструктурированные глубинные интервью затрагивали чувствительные аспекты брачной и репродуктивной истории информанток, их сексуальной жизни, включая опыт тестирования на ВИЧ/ИППП и стратегии снижения сексуальных рисков. Глубинные интервью также проводились женщинами-интервьюерами соответствующей этнической принадлежности на одном из четырех основных языков исследования по

Киргизской Республики, прибывающими для постоянного проживания в Российскую Федерацию, и выхода из прежнего гражданства». 
выбору информанток. После завершения интервью женщины получали дополнительное вознаграждение за участие.

Интервью с работниками сферы здравоохранения. На завершающем этапе сбора данных мы провели интервью с девятью врачами-гинекологами, пять интервью было проведено в Москве, 4 - в Новосибирске. В Москве врачи, с которыми проводились интервью, работали в частных медицинских центрах, которые обслуживают преимущественно мигрантов, один врач работал в сети телефонных медицинских консультаций, созданной при посредничестве памирской общины «Нур» и представительства фонда Ага-Хана. В Новосибирске интервью были проведены с двумя сотрудниками государственных учреждений (женская консультация и смотровой кабинет в государственной поликлинике), еще два врача-гинеколога были заняты в коммерческих медицинских центрах. Интервью с врачами затрагивали вопросы их опыта по взаимодействию с пациентками-мигрантами, потребности женщин-мигрантов в сфере сексуального и репродуктивного здоровья, восприятие врачами рисков ВИЧ/ИППП среди женщин-мигрантов, оценку факторов, оказывающих влияние на данные риски, опыт врачей по тестированию на ВИЧ/ИППП, консультированию и лечению, консультированию по применению контрацептивов и по поводу ведения и прерывания беременности.

\section{МЕТоды}

На первом этапе анализа количественных данных мы исследовали зависимость между этнокультурными характеристиками, социально-экономическим положением женщинмигрантов и переменными, связанными с поведенческими стратегиями и восприятием рисков; затем был проведен мультивариантный статистический анализ. Для анализа каждой зависимой переменной мы применяли две модели: в первой модели для каждой пары данных сравнивали местных женщин с мигрантами без выделения отдельных этнических групп среди мигрантов. Во второй модели анализировали только женщинмигрантов для того, чтобы выявить различия между этническими группами и изучить различия между мигрантами, имеющими и не имеющими российское гражданство. В данных моделях мы анализировали роль демографических и социально-экономических характеристик респонденток, длительности их проживания в городе, где было проведено интервью, и социальных связей. Для статистического анализа использовали пакеты SAS и STATA.

Статистический анализ был дополнен анализом данных глубинных интервью и интервью с работниками сферы здравоохранения. Нужно подчеркнуть, что качественные данные не могут быть напрямую соотнесены с результатами статистического анализа, однако они дополнительно иллюстрируют сложные взаимосвязи этнокультурных и социально-экономических характеристик и правового статуса в жизни женщин-мигрантов, которые влияют на их подверженность риску ВИЧ/ИППП. 


\section{РезУльтаты}

\section{Описательный анализ}

В таблице 3 представлено распределение зависимых переменных по этническим группам и городам проведения исследования. В таблице указано число сексуальных партнеров опрошенных женщин за 12 месяцев перед анкетированием. Как видно, в группе местных женщин среднее число сексуальных партнеров превышает аналогичный показатель в любой из трех этнических групп мигрантов. Однако стоит обратить внимание на различия среди групп мигрантов. В частности, среднее число сексуальных партнеров у киргизок превышает данных показатель у узбечек и особенно у таджичек. Киргизские женщины также значительно отличались от узбечек и таджичек по частоте вступления в половую связь в состоянии опьянения, по данному показателю они вплотную приближаются к местным женщинам.

Далее в таблице следуют характеристики, описывающие отношения женщин с их постоянными партнерами. Интересно отметить, что среди местных женщин зафиксирован самый высокий уровень доверия их постоянным партнерам (особенно в Новосибирске и Екатеринбурге). Свыше 70\% местных женщин убеждены в том, что их партнер не имеет сексуальных отношений с другими женщинами, тогда как аналогичную убежденность продемонстрировали менее половины киргизских и таджикских женщин. Местные женщины также, в среднем, наиболее убеждены в том, что их партнер согласится на использование презерватива, если они его об этом попросят; узбекские женщины, работающие в Москве, продемонстрировали самый низкий уровень убежденности в этом. Для московских узбечек также зафиксирован наименьший процент тех, кто отказал своему партнеру в сексе как минимум один раз за последние четыре недели. Интересно отметить, что среди всех рассматриваемых групп киргизские женщины были наиболее склонны отказывать партнеру в сексе: доля киргизок, которые отказали партнеру в сексе хотя бы один раз, превышала аналогичный показатель для таджичек почти в два раза. Удивительно, что таджички продемонстрировали самый высокий уровень использования презервативов с постоянным партнером, причем как с целью предотвращения беременности, так и для защиты от ВИЧ/ИППП; самый высокий процент отмечен среди таджичек в Москве.

Последние две характеристики в таблице 3 - обеспокоенность риском заражения ВИЧ и сдача анализа на ВИЧ. Почти половина опрошенных женщин сказали, что они очень обеспокоены или в некоторой степени обеспокоены риском инфицирования. Здесь выделяется группа таджичек, в которой уровень обеспокоенности значительно ниже, чем у всех остальных групп. Местные женщины были в целом менее склонны выражать беспокойство риском инфицирования, чем киргизки и узбечки. Среди местных женщин самая большая доля тех, кто сдавал анализ на ВИЧ за последние два года, однако разница между ними и группами киргизок и узбечек незначительна (отметим, что для киргизок в Москве зафиксирован противоположный эффект: там доля сдававших анализ выше, чем среди остальных групп женщин). По этому показателю снова выделяются таджички, у которых среднее число сдававших анализ на ВИЧ за последние два года ниже, чем у 
других групп (в первую очередь за счет очень малого процента сдававших анализ в Москве).

Таблица 3. Характеристики респонденток, связанные с сексуальным поведением и рисками

\begin{tabular}{l|c|c|c|c|c|}
\hline \multirow{2}{*}{ Город } & \multicolumn{3}{|c|}{ Этническая группа } & \multirow{2}{*}{ Всего } \\
\cline { 2 - 5 } & киргизки & таджички & узбечки & местные & \multirow{2}{*}{} \\
\hline
\end{tabular}

Количество сексуальных партнеров за последние 12 месяцев, человек (среди тех, кто имел сексуальный контакт за последние 12 месяцев, $\mathrm{n}=652$ )

$\begin{array}{llllll}\text { Всего } & 1,4 & 1,0 & 1,2 & 1,7 & 1,3 \\ \text { Москва } & 1,5 & 1,0 & 1,2 & 1,7 & 1,4 \\ \text { Новосибирск и Екатеринбург } & 1,1 & 1,1 & 1,1 & 1,6 & 1,3\end{array}$

Вступали в половые отношения в последние 4 недели в состоянии алкогольного опьянения (среди тех, кто имел половые отношения за последние 4 недели, $\mathrm{n}=564), \%$

$\begin{array}{lccccc}\text { Всего } & 34 & 4 & 4 & 34 & 22 \\ \text { Москва } & 43 & 0 & 8 & 30 & 20 \\ \text { Новосибирск и Екатеринбург } & 21 & 10 & 17 & 38 & 24\end{array}$

Доверяют постоянному партнеру (среди имеющих постоянного партнера, $\mathrm{n}=645$ ), \%

$\begin{array}{llllll}\text { Всего } & 48 & 48 & 65 & 71 & 58 \\ \text { Москва } & 37 & 44 & 66 & 65 & 53 \\ \text { Новосибирск и Екатеринбург } & 66 & 54 & 62 & 80 & 66\end{array}$

Считают, что постоянный партнер согласится на использование презерватива (среди тех, кто ведет активную половую жизнь с постоянным партнером, $\mathrm{n}=565), \%$

$\begin{array}{llllll}\text { Всего } & 43 & 52 & 37 & 64 & 50 \\ \text { Москва } & 33 & 46 & 17 & 63 & 40 \\ \text { Новосибирск и Екатеринбург } & 60 & 63 & 68 & 66 & 65\end{array}$

Отказали постоянному партнеру в сексе как минимум один раз за последние 12 месяцев (среди тех, кто имел половые отношения с постоянным партнером как минимум один раз за последние 12 месяцев, $\mathrm{n}=562), \%$

$\begin{array}{llllll}\text { Всего } & 63 & 33 & 46 & 55 & 50 \\ \text { Москва } & 61 & 33 & 24 & 46 & 41 \\ \text { Новосибирск и Екатеринбург } & 65 & 32 & 77 & 67 & 63\end{array}$

Регулярно использовали презерватив с постоянным партнером за последние 4 недели (среди тех, кто имел половые отношения с постоянным партнером как минимум один раз за последние 4 недели, $\mathrm{n}=$ 486), \%

$\begin{array}{llcccr}\text { Всего } & 8 & 22 & 9 & 14 & 13 \\ \text { Москва } & 8 & 28 & 0 & 11 & 12 \\ \text { Новосибирск и Екатеринбург } & 9 & 11 & 20 & 17 & 15\end{array}$

Очень обеспокоены или обеспокоены риском ВИЧ (среди тех, кто имел половые отношения за последние 4 недели, $\mathrm{n}=564), \%$

\begin{tabular}{lccccc} 
Всего & 53 & 32 & 55 & 45 & 47 \\
Москва & 52 & 41 & 60 & 43 & 49 \\
Новосибирск и Екатеринбург & 54 & 15 & 48 & 47 & 43 \\
Вали анализ на ВИЧ за последние 2 года, \% & & & & 51 \\
Всего & 52 & 34 & 56 & 60 & 54 \\
Москва & 72 & 21 & 60 & 65 & 45 \\
Новосибирск и Екатеринбург & 23 & 53 & 49 & 53 & \\
\hline
\end{tabular}

\section{Мультивариантный анализ}

Данные, представленные в таблице 3, указывают на ряд устойчивых паттернов, а также выявляют значительные различия между изучаемыми этническими группами и между городами, где проводилось исследование. Для того, чтобы исследовать эффект различных факторов на зависимые переменные, мы использовали мультивариантный анализ. Результаты анализа рискованного сексуального поведения, обеспокоенности 
риском ВИЧ и опыта тестирования на ВИЧ представлены в таблице 4. Сначала мы проанализировали число сексуальных партнеров за последние 12 месяцев, используя регрессию Пуассона. Анализ проводили по двум моделям: в первой модели сравнивали женщин-мигрантов с контрольной группой местных женщин; во второй модели сравнение проводили только между этническими группами мигрантов. Коэффициенты этих двух моделей представлены в первом разделе таблицы 4. Результаты первой модели демонстрируют значительное сходство с паттернами, выявленными в описательном анализе, и показывают, что независимо от других факторов местные женщины имели значительно более высокое среднее число сексуальных партнеров за последние 12 месяцев, чем женщины-мигранты. Вторая модель, в которую были включены только мигранты, показала, что узбечки и киргизки имели значительно большее число сексуальных партнеров, чем таджички (разница между киргизками и узбечками не является статистически значимой).

\section{Таблица 4. Число сексуальных партнеров и секс в состоянии алкогольного опьянения; коэффициенты регрессии Пуассона и логистической регрессии}

\begin{tabular}{|c|c|c|c|c|c|c|c|c|}
\hline \multirow[t]{2}{*}{ Независимые и контрольные переменные } & \multicolumn{4}{|c|}{$\begin{array}{c}\text { Число сексуальных } \\
\text { партнеров за последние } \\
12 \text { месяцев }\end{array}$} & \multicolumn{4}{|c|}{$\begin{array}{c}\text { Вступали в половую связь в } \\
\text { состоянии опьянения за } \\
\text { последние } 4 \text { недели (среди } \\
\text { тех, кто имел половые } \\
\text { отношения за последние } \\
4 \text { недели) }\end{array}$} \\
\hline & & sce & мигра & Нты & $\mathrm{BC}$ & & миграң & нты \\
\hline Местные женщины & 0,582 & $* *$ & & & 0,629 & & & \\
\hline Киргизки & & & 0,610 & $* *$ & & & 3,024 & ** \\
\hline Узбечки & & & 0,521 & $* *$ & & & 2,255 & ** \\
\hline Гражданство РФ & & & 0,090 & & & & 0,574 & \\
\hline В зарегистрированном браке & & & & & $-0,885$ & ** & $-1,188$ & ** \\
\hline Москва & 0,140 & + & 0,263 & * & $-0,121$ & & 0,399 & \\
\hline Заняты в формальной торговле (магазины) & $-0,230$ & $* *$ & $-0,228$ & * & $-0,871$ & ** & $-0,832$ & * \\
\hline Заняты в сфере общественного питания & $-0,151$ & + & $-0,250$ & $*$ & $-0,906$ & ** & $-0,505$ & \\
\hline $\begin{array}{l}\text { Имеют высшее или неоконченное высшее } \\
\text { образование }\end{array}$ & 0,180 & $* *$ & 0,074 & & 0,264 & & 0,167 & \\
\hline Месячный доход, тыс. руб. & 0,004 & ** & 0,003 & & 0,020 & ** & 0,030 & + \\
\hline $\begin{array}{l}\text { Число людей, ночующих в одной комнате с } \\
\text { респонденткой }\end{array}$ & $-0,006$ & & $-0,002$ & & 0,119 & + & 0,025 & \\
\hline $\begin{array}{l}\text { Число лет, которое респондентка непрерывно } \\
\text { живёт в городе }\end{array}$ & 0,018 & & 0,031 & + & 0,068 & + & 0,110 & + \\
\hline Есть близкий взрослый родственник в городе & $-0,048$ & & 0,019 & & 0,074 & & 0,249 & \\
\hline Возраст & 0,007 & & 0,020 & $* *$ & $-0,046$ & $*$ & $-0,055$ & + \\
\hline Константа & $-0,621$ & $* *$ & $-1,588$ & $* *$ & $-0,491$ & & $-3,135$ & ** \\
\hline Число респонденток в анализе & 940 & & 693 & & 562 & & 389 & \\
\hline
\end{tabular}

Модель, представленная во второй секции таблицы 4, показывает вероятность вступления в сексуальную связь в состоянии алкогольного опьянения в течение четырёх месяцев, предшествующих интервью. Анализ проведен с использованием биномиальной логистической регрессии; в анализ были включены только те женщины, которые имели половые связи за последние 12 месяцев. Первая модель демонстрирует 
статистически значимую разницу между местными женщинами и женщинамимигрантами: при прочих равных условиях для местных женщин вероятность вступления в сексуальный контакт в состоянии опьянения значительно выше. Однако вторая модель вносит важные коррективы в данное заключение: как среди узбечек, так и среди киргизок вероятность сексуального контакта в состоянии опьянения значительно выше, чем для таджикских женщин, что совпадает с контрастом между таджичками и двумя другими группами мигрантов, выявленным при анализе числа сексуальных партнёров. Когда мы сравнили узбечек и киргизок с местными женщинами, различия оказались статистически незначимыми (не показано в таблице).

Результаты двух моделей логистической регрессии, представленные в таблице 5, описывают отношения респонденток с их постоянными партнерами и соответственно ограничены подвыборкой женщин, которые имеют таких партнеров. Поскольку риски женщин в большей степени определяются поведением их партнеров, нежели их собственным, важно проследить динамику отношений с партнерами. Первая пара моделей показывает степень доверия партнерам в том, что они не имеют сексуальных контактов с другими женщинами. Результаты демонстрируют, что в целом местные женщины в значительно большей степени склонны доверять партнерам, чем мигранты. Здесь также выявлены различия между этническими группами мигрантов: киргизки по данному показателю не отличаются от таджичек, в то время как узбечки в большей степени, чем таджички, склонны верить в то, что их партнеры не имеют сексуальных контактов с другими женщинами. При этом разница между двумя последними группами находится на пределе статистической значимости $(p<0,10)$. Такая же статистически маргинальная разница по этому показателю выявлена между узбечками и киргизками (не показана в таблице).

На следующем этапе анализа независимой переменной была следующая дихотомия: отказывала ли респондентка своему постоянному партнеру в сексе за последние 12 месяцев. Местные женщины с большей вероятностью склонны отказать партнеру в сексе, чем мигранты. Результаты анализа, где сравниваются между собой только представительницы трех этнических групп мигрантов, показывают значительные различия между таджичками (референтной группой), с одной стороны, и узбечками и киргизками, с другой стороны. При прочих равных условиях таджички были в значительной степени менее склонны отказывать регулярному партнеру в сексе, чем узбечки и киргизки. Между киргизками и узбечками также отмечены небольшие различия (не показаны в таблице): киргизки по сравнению с узбечками были более склонны отказать постоянному партнеру в сексе. Полученные данные указывают на важные различия в системе гендерных отношений, которые существуют в трех мигрантских этнических группах и могут быть значимы при оценке рисков ВИЧ/ИППП для данных групп. 
Таблица 5. Отношения с постоянным партнером; коэффициенты логистической регрессии

\begin{tabular}{|c|c|c|c|c|c|c|c|c|c|c|c|c|c|c|c|c|}
\hline \multirow[t]{2}{*}{ Независимые и контрольные переменные } & \multicolumn{4}{|c|}{$\begin{array}{c}\text { Доверяет партнёру в } \\
\text { том, что у него нет } \\
\text { связей с другими } \\
\text { женщинами }\end{array}$} & \multicolumn{4}{|c|}{$\begin{array}{c}\text { Отказала партнёру в } \\
\text { сексе (среди тех, кто } \\
\text { ведёт активную } \\
\text { половую жизнь с } \\
\text { партнером) }\end{array}$} & \multicolumn{4}{|c|}{$\begin{array}{c}\text { Считает, что партнер } \\
\text { согласится на } \\
\text { использование } \\
\text { презерватива }\end{array}$} & \multicolumn{4}{|c|}{$\begin{array}{c}\text { Регулярное } \\
\text { использование } \\
\text { презерватива с } \\
\text { партнером для } \\
\text { защиты от ИППП }\end{array}$} \\
\hline & \multicolumn{2}{|c|}{ Bce } & \multicolumn{2}{|c|}{ мигранты } & \multicolumn{2}{|c|}{ Bce } & \multicolumn{2}{|c|}{ мигранты } & \multicolumn{2}{|l|}{ Bce } & \multicolumn{2}{|c|}{ мигранты } & \multicolumn{2}{|l|}{ все } & \multicolumn{2}{|c|}{ мигранты } \\
\hline Местные женщины & 0,724 & $* *$ & & & 0,587 & $*$ & & & 0,478 & * & & & $-0,555$ & & & \\
\hline Киргизки & & & $-0,035$ & & & & 1,341 & $* *$ & & & $-0,523$ & & & & $-0,708$ & \\
\hline Узбечки & & & 0,459 & + & & & 0,607 & $*$ & & & $-0,702$ & * & & & $-1,046$ & * \\
\hline Гражданство РФ & & & $-0,045$ & & & & $-0,160$ & & & & $-0,108$ & & & & $-1,037$ & + \\
\hline Возраст & $-0,034$ & * & $-0,050$ & $* *$ & 0,006 & & 0,006 & & $-0,005$ & & $-0,027$ & & 0,021 & & 0,028 & \\
\hline В зарегистрированном браке & 1,066 & $* *$ & 1,236 & $* *$ & 0,161 & & 0,084 & & $-0,509$ & $* *$ & $-0,694$ & $* *$ & $-1,084$ & $* *$ & $-0,880$ & * \\
\hline Москва & $-0,178$ & & $-0,077$ & & $-1,026$ & $* *$ & $-0,860$ & $* *$ & $-1,009$ & $* *$ & $-1,380$ & $* *$ & 0,177 & & $-0,270$ & \\
\hline Заняты в формальной торговле (магазины) & 0,384 & + & 0,301 & & $-0,491$ & * & $-0,835$ & $* *$ & $-0,228$ & & $-0,498$ & + & 0,022 & & 0,059 & \\
\hline Заняты в сфере общественного питания & 0,194 & & 0,314 & & $-0,654$ & $* *$ & $-1,103$ & $* *$ & 0,010 & & $-0,432$ & & 0,542 & & 0,400 & \\
\hline Имеют высшее или неоконченное высшее образование & 0,158 & & 0,367 & & 0,194 & & 0,068 & & 0,264 & & 0,302 & & 0,301 & & 0,386 & \\
\hline $\begin{array}{l}\text { Месячный доход, тыс. руб. } \\
\text { Число людей, ночующих в одной комнате с }\end{array}$ & $-0,016$ & * & $-0,012$ & & 0,012 & + & 0,007 & & 0,009 & & 0,005 & & $-0,001$ & & 0,002 & \\
\hline респонденткой & $-0,140$ & $* *$ & $-0,154$ & $* *$ & 0,052 & & $-0,015$ & & $-0,073$ & & $-0,047$ & & $-0,068$ & & $-0,013$ & \\
\hline Число лет, которое респондентка живет в городе & 0,029 & & 0,043 & & $-0,059$ & + & $-0,030$ & & 0,022 & & 0,047 & & 0,093 & + & 0,148 & * \\
\hline Есть близкий взрослый родственник в городе & $-0,055$ & & 0,092 & & $-0,145$ & & $-0,100$ & & 0,087 & & $-0,103$ & & $-0,280$ & & $-0,215$ & \\
\hline Доверяет партнеру & & & & & & & & & & & & & $-0,180$ & & 0,212 & \\
\hline Константа & 1,172 & * & 1,103 & + & 0,399 & & 0,134 & & 0,670 & & 2,373 & $* *$ & $-2,431$ & $*$ & $-2,535$ & + \\
\hline Число респонденток в анализе & 642 & & 471 & & 561 & & 393 & & 564 & & 394 & & 480 & & 330 & \\
\hline
\end{tabular}

Примечание: Референтные категории: мигранты, таджички, не граждане РФ, не в зарегистрированном браке, Новосибирск или Екатеринбург, работают на рынке, образование среднее или ниже среднего, нет близких родственников в городе, подозревает партнера в том, что он изменяет или не вполне уверена.

Уровни статистической значимости: $* *$ - $p<0,01, *-p<0,05,+-p<0,10$. 
Затем мы применили две модели логистической регрессии, чтобы оценить вероятность того, что постоянный партнер, с которым респондентка имела сексуальные контакты в последние 12 месяцев, согласится, по ее мнению, на использование презерватива. Полученные результаты представлены в третьем разделе таблицы 5. Модель, в которой сравнивались местные женщины и мигрантки, показала, что первые в значительно большей степени склонны согласиться на использование презервативов. Во второй модели, где сравнивались женщины-мигранты из разных этнических групп, результаты показывают, что отличия узбечек от референтной группы являются статистически значимыми: партнеры узбекских женщин с меньшей вероятностью согласятся на использование презервативов, чем партнеры таджикских женщин (различия между узбечками и киргизками не являются статистически значимыми). Результаты указывают на то, что в сравнении с местными женщинами женщинымигранты имеют меньше возможностей настаивать на безопасном сексе. Однако выявленные различия между этническими группами женщин-мигрантов требуют дальнейшего исследования.

Наконец, мы проанализировали вероятность постоянного использования презервативов во время вагинального секса с регулярным партнером за последние 4 недели перед интервью с целью защиты от ВИЧ/ИППП (последний раздел таблицы 5). В анализ были включены только респондентки, сообщившие о сексуальных контактах в указанный период. При сравнении местных женщин и женщин-мигрантов различий выявлено не было. Однако вторая модель, где сравнивались три мигрантские этнические группы между собой, выявила яркие различия между таджичками и группами киргизок и узбечек, которые изначально проявились в описательном анализе. Даже с учетом многих других факторов, включая тип брачных отношений (официально зарегистрированный брак или незарегистрированные отношения) и доверие постоянному партнеру, для таджичек выявлена значительно более высокая вероятность постоянного использования презервативов по сравнению с киргизками и узбечками. Данный феномен требует дальнейшего изучения.

В таблице 6 представлены результаты логистической регрессионной модели обеспокоенности риском ВИЧ-инфицирования среди респонденток, которые имели сексуальные контакты в последние 12 месяцев. Сравнение местных женщин с мигрантами не показывает статистически значимых различий между двумя группами, а при сравнении этнических групп киргизок, узбечек и таджичек между собой снова выделяются таджички, которые в меньшей степени склонны выражать обеспокоенность риском ВИЧ-инфицирования, чем представительницы двух других групп. Мы экспериментировали с различными формулировками моделей, добавив для контроля несколько дополнительных переменных, но различия между таджичками и двумя другими группами оставались статистически значимыми (результаты экспериментальных моделей не показаны в таблице). Этот интересный результат также требует дальнейшего изучения. 


\section{Таблица 6. Обеспокоенность риском ВИЧ и опыт сдачи анализов на ВИЧ, коэффициенты логистической регрессии}

\begin{tabular}{|c|c|c|c|c|c|c|c|c|}
\hline \multirow[t]{2}{*}{$\begin{array}{l}\text { Независимые и контрольные } \\
\text { переменные }\end{array}$} & \multicolumn{4}{|c|}{$\begin{array}{c}\text { Обеспокоены риском ВИЧ- } \\
\text { инфицирования (среди тех, кто } \\
\text { имел половые отношения за } \\
\text { последние } 12 \text { месяцев) } \\
\end{array}$} & \multicolumn{4}{|c|}{$\begin{array}{c}\text { Сдавали анализ на ВИЧ за } \\
\text { последние } 2 \text { года }\end{array}$} \\
\hline & \multicolumn{2}{|c|}{ все } & \multicolumn{2}{|c|}{ мигранты } & \multicolumn{2}{|c|}{ все } & \multicolumn{2}{|c|}{ мигранты } \\
\hline Местные женщины & $-0,033$ & & & & 0,892 & & & \\
\hline Киргизки & & & 1,144 & $* *$ & & & 0,327 & \\
\hline Узбечки & & & 1,128 & $* *$ & & & 0,956 & ** \\
\hline Гражданство РФ & & & $-0,367$ & & & & 0,471 & * \\
\hline В зарегистрированном браке & $-0,756$ & ** & $-0,786$ & ** & 0,298 & $*$ & 0,326 & + \\
\hline Москва & 0,100 & & 0,226 & & 0,100 & & 0,080 & \\
\hline $\begin{array}{l}\text { Заняты в формальной торговле } \\
\text { (магазины) }\end{array}$ & 0,040 & & 0,153 & & 0,929 & ** & 0,886 & ** \\
\hline $\begin{array}{l}\text { Заняты в сфере общественного } \\
\text { питания }\end{array}$ & 0,041 & & 0,107 & & 1,064 & ** & 1,219 & ** \\
\hline Имеют высшее или неоконченное & - 310 & + & -0486 & + & O 110 & & 0145 & \\
\hline Месячный доход, тыс. руб. & $-0,002$ & 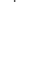 & $\begin{array}{r}-0,480 \\
0,003\end{array}$ & 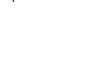 & 0,119 & & $\begin{array}{l}0,145 \\
0,026\end{array}$ & ** \\
\hline $\begin{array}{l}\text { Число людей, ночующих в одной } \\
\text { комнате с респонденткой } \\
\text { Число лет, которое респондентка }\end{array}$ & 0,130 & ** & 0,106 & + & 0,085 & * & 0,095 & * \\
\hline $\begin{array}{l}\text { живет в городе } \\
\text { Есть близкий взрослый }\end{array}$ & 0,007 & & 0,038 & & $-0,028$ & & $-0,056$ & \\
\hline родственник в городе & 0,197 & & 0,473 & * & $-0,299$ & + & $-0,227$ & \\
\hline Возраст & $-0,040$ & ** & $-0,045$ & * & $-0,003$ & & $-0,022$ & \\
\hline Константа & 1,041 & $*$ & 0,029 & & $-0,893$ & $*$ & $-1,409$ & ** \\
\hline Число респонденток в анализе & 651 & & 427 & & 940 & & 693 & \\
\hline
\end{tabular}

Примечание: Референтные категории: мигранты, таджички, не граждане РФ, не в зарегистрированном браке, Новосибирск или Екатеринбург, работают на рынке, образование среднее или ниже среднего, нет близких родственников в городе. Уровни статистической значимости: $* *-p<0,01, *-p<0,05,+-p<0,10$.

Второй раздел таблицы 6 показывает результаты логистической регрессии вероятности сдачи анализа на ВИЧ в последние два года. Как видно из таблицы 3 , процент женщин, сдавших анализ на ВИЧ в этот период, был выше среди местных женщин. Мультивариантный анализ подтверждает эту тенденцию - среди мигрантов доля сдававших анализ меньше независимо от других характеристик. Когда мы исключили местных женщин и провели сравнение этнических групп женщинмигрантов, между ними обозначились немалые различия. Так, у таджичек вероятность сдачи анализа была более высокой, чем у узбечек. Разница между таджичками и киргизками также прослеживается, но не является статистически значимой. Отметим, что среди женщин, занятых на предприятиях общепита и в магазинах, где правила получения медицинской книжки (для которой требуется сдача анализа на ВИЧ) обычно более строго выполняются, доля сдававших анализ на ВИЧ была выше, чем среди женщин, работающих на рынках. Образование не оказывает влияния на вероятность сдачи анализа на ВИЧ. Интересно, что уровень доходов имеет положительный эффект только в модели, где этнические группы мигрантов сравнивались между собой. В этой модели наличие российского гражданства значительно повышает вероятность сдачи анализа на ВИЧ. 


\section{Иллюстрации из глубинных интервью}

Глубинные интервью позволили получить дополнительную информацию о сексуальном опыте и поведении мигрантов и их сексуальных рисках. Так, женщины отмечали, что моногамный брак, в котором партнеры хранят верность друг другу, является самым предпочтительным видом отношений по многим причинам, включая предотвращение рисков ВИЧ/ИППП. Как отметила киргизская респондентка: “Я стараюсь инфекцию не подпускать. Я же тоже выбираю, без разбора не сплю, потому что в таком случае обязательно какая-нибудь инфекция. А так, если только один партнер и если нет измены, то ничего не пристанет”.

Однако реальность брачных и сексуальных отношений в России зачастую очень отличается от этой идеальной модели. Истории респонденток часто затрагивали изменения, которые случились с их браком после приезда в Россию. Респонденткаузбечка рассказала, как ее брак начал разрушаться и трагически завершился: “Перед тем, как приехать в Новосибирск, мы сначала жили в Курской области. С мужем, свекровью, свекром мы жили и работали нормально. Нормально торговали. Но в натей жизни то одно, то другое было, жизненные проблемы, ссоры, ругань между мужем и женой. Муж там испортился и начал гулять, изменять с девушками. Я родила сына. Муж стал пьянствовать. По-моему, даже поддался наркотикам, не знаю. Потом до такой степени было, что мы чуть не дошли до развода. Ну не знаю, что-то случилось, он запил, повесился и умер. Мы его там похоронили”.

Женщины отмечали в интервью значительные и обычно разрушительные эффекты влияния иной социокультурной среды и экономических трудностей, с которыми они сталкиваются в России, на их морально-этические представления и взаимоотношения. Рассказывает киргизка из Москвы:

"Я очень много своих землячек вижу, они сюда приезжают, молодые, они сразу же изменяются. Они меняются, они, наверное, думают, это далеко, это в Москве, никто не увидит, никто не усльшит, и они... очень развратными и вульгарными становятся и ведут себя, а на Родине они себя так не ведут. А у нас на родине всё [все нормы] соблюдается, хоть они здесь себя вульгарно ведут, а там, на родине, нет. Да очень меняются и замужние тоже... Мужья здесь много пьют, курят, гуляют. Если бы они из города приехали, они бы такого не позволили себе. В основном это с горных сел или из [сельских] регионов приезжают и думают, что им все дозволено. Раз русские так поступают, значит им тоже можно. Кто из горных районов приезжает, там они ничего не видели, а здесь они думают, что им все позволено. Те замужние женщины, которые с мужьями сюда приезжают, 50-60\% разводятся после жизни в Москве. Это из-за жилищных условий, я думаю, потому что негде поговорить, негде нормально пообщаться, негде нормально "поспать" (заняться сексом); из-за этого браки распадаются".

Женщины-мигранты в стремлении к длительным устойчивым отношениям часто терпят плохое обращение партнеров в надежде создать стабильный союз. Респонденткатаджичка рассказала о своей знакомой: 
“Она в этом году закончила школу и приехала в Москву. Здесь познакомилась с одним парнем, он на четырнадцать лет старще неё; обещал ей жениться, и она согласилась с ним жить вместе. Она думала, что в скором времени он женится на ней, но он каждый раз обманывает ее, не хочет жениться. Они уже год вместе живут половой жизнью; она, бедная, надеется, что он женится на ней. Никто из родных не знает о том, что она живёт с парнем; она всех обманула, сказала, что живёт с двоюродной сестрой. Она всегда плачет, не знает, что ей делать”.

В силу традиционных культурных норм женщины-мигранты не хотят идти на разрыв отношений с изменяющими и плохо обращающимися с ними мужчинами. Так, к примеру, респондентка-таджичка рассказала, что, когда она узнала, что ее муж изменяет ей с другой женщиной (также замужней), она попыталась убедить мужа прекратить эту связь. Однако, несмотря на ее усилия, муж продолжал встречаться с той женщиной.

Некоторые женщины во время интервью признавали реалии более раскрепощенных сексуальных норм, говоря как о неизбежном факте, что мужчины имеют многих сексуальных партнерш. Однако многие респондентки говорили и о своем страхе инфицирования ВИЧ/ИППП; при этом они были убеждены в том, что постоянное использование презерватива защитит их от рисков. В наибольшей степени это относится к киргизским женщинам, которые происходят из среды с менее консервативными культурными и религиозными традициями, нежели таджички и узбечки. Вот история, которую рассказала одна киргизская респондентка:

“Конечно, есть обеспокоенность [риском инфицирования], поэтому я всегда пользуюсь презервативом. Я у них не одна [девушка], а у мужчин тем более бывает по 5-6 девушек, как им доверять? У каждой женщины должна быть своя голова на плечах. Вот у меня, например, если захочу, будет 4-5 мужчин, если не захочу, только одного буду иметь, это от меня зависит. Я не загуляла, не запила, работаю, в выходные дни встречаюсь [с мужчинами], потому что мы женщины, взрослые уже. Каждая женщина должна мозги иметь, я так понимаю. Для меня, например, нормально, если я встречалась с тремя - четырьмя - пятью [мужчинами], это нормально, я же с умом это делаю, это все временно”.

\section{Иллюстрации из интервью с врачами}

Беседы с работниками сферы здравоохранения помогли дополнить представления о природе и структуре рисков ВИЧ/ИППП. Они отмечали, что самые высокие риски инфицирования характерны для молодых девушек. Рассказывает врач-гинеколог из Москвы: "В основном инфицируется молодёжь. Во-первых, они не знают, как предохраняться от инфекиий, передающихся половым путём. И не лечатся [от инфекций]. Купили таблетки, попили, заглушили процесс и дальше... Проблема стоит остро”.

Врач из Новосибирска связал риски инфекций, передающихся половым путем, с брачными отношениями: "К нам обращается много киргизок и узбечек. Во-первых, проблемы связаны с очень ранним замужеством. Я думаю, что когда они выходят замуж, 
у них появляется очень много инфекций. Потому что мужья не обследованные... У приезжих сексуальные риски в основном связаны с мужьями”.

Наблюдения врача-гинеколога из московского медицинского центра объясняют механизм распространения и выявления инфекций среди мигрантов:

“Инфекций, передающихся половым путём, много [у женщин-мигрантов]. Особенно у молодёжи. Они не предохраняются. Видимо, у них [на родине] живут все строго, а сюда приехали, и происходит бог весть что. Один с другим, вторая ещё с кемто, переспали без предохранения и всё... Обычно как получается? К нам приходит молодая девушка, которая недавно вышла замуж, и говорит, что не может забеременеть, бесплодие. А в нашей культуре в этом обычно винят женщину, мол, бесплодная. Мы говорим, чтобы приводила мужа на прием. Когда проводим анализ на инфекции, выясняется, что у жены такая-то инфекция. Они [мужчины] боятся того, что скажут, что изменяет. А мы объясняем, что парень до женитьбы нагулял. А некоторые и после женитьбы гуляют".

Интервью с врачами помогли проследить взаимосвязь между репродуктивным здоровьем женщин и сексуальными рисками. Инфекции, передающиеся половым путем, в особенности те, которые не дают четкой симптоматики, обычно выявляются во время осмотров при беременности, а также в других ситуациях, когда женщины обращаются к медикам за консультацией. Таким образом, визит к врачу-гинекологу является одним из немногих доступных женщинам-мигрантам способов получить консультацию по поводу предотвращения рисков ВИЧ/ИППП.

\section{ЗАКЛЮЧЕНИЕ}

Результаты, представленные в статье, показывают различия как между женщинамимигрантами и местными женщинами, так и между тремя этническими группами мигранток (киргизки, таджички, узбечки) в сфере восприятия рисков ВИЧ/ИППП и тестирования на эти инфекции, сексуального опыта и управления рисками. Включение в исследование контрольной группы местных женщин, работающих в тех же отраслях и имеющих сходные занятия, помогает выделить специфику рисков женщин-мигрантов. В частности, результаты показывают, что местные женщины обычно имеют больше сексуальных партнеров, чем женщины-мигранты. Однако большее среднее число сексуальных партнеров у местных женщин соответствует более либеральной сексуальной культуре, в которой они воспитаны. Таким образом, можно предположить, что местные женщины, как правило, лучше подготовлены к профилактике потенциальных рисков, связанных с большим количеством партнеров или нестабильными отношениями. Также можно считать, что местные женщины склонны вступать в более эгалитарные отношения, в которых измена партнеров-мужчин менее вероятна. В любом случае, местные женщины могут иметь более широкие возможности для разрыва отношений, если они подозревают партнеров в связях с другими женщинами и/или считают, что сексуальные контакты партнеров с другими женщинами ставят их под угрозу заражения ВИЧ/ИППП. Местные женщины также имеют 
значительное преимущество в управлении рисками по сравнению с мигрантками в силу лучшего доступа к услугам бесплатной медицины - возможности посещать женские консультации и врачей-гинекологов, ведения беременности и лечения инфекций.

Женщины-мигранты из Средней Азии, как правило, являются носителями более традиционной культуры, где сильнее ограничены сексуальные свободы женщин и в то же время больше ограничена возможность руководствоваться собственным выбором при вступлении в половые отношения. Эти культурные нормы, потенциально защищающие женщин в стране происхождения мигрантов, могут становиться неэффективными или даже контрэффективными в российском контексте, поскольку они мешают женщинам-мигрантам адекватно оценивать риски и принимать меры для их минимизации либо путем договоренности с партнером, либо прекращая отношения, в которых не могут быть достигнуты такие договоренности, либо обращаясь за профессиональной медицинской помощью.

Выявленные различия между этническими группами женщин-мигрантов требуют более детальной оценки рисков ВИЧ. Наиболее интригующим является очевидный контраст между таджичками и представительницами двух других групп по ряду параметров. Поскольку у нас нет оснований подозревать, что качество собранных данных систематически варьировалось в разных этнических группах, мы предлагаем искать ключ к этим различиям в этнокультурных характеристиках и миграционном опыте разных групп мигрантов. Однако более полное объяснение этих различий потребует дополнительного изучения.

В целом представленное исследование вносит вклад в понимание проблематики гендерно-специфических рисков ВИЧ/ИППП среди международных мигрантов в России. Проведённый анализ уязвимости женщин-мигрантов из Средней Азии иллюстрирует взаимосвязь правовых, этнокультурных, и социально-экономических факторов, которые влияют на эти риски. Хотя результаты исследования могут иметь большое прикладное значение, мы воздерживаемся от каких-либо практических рекомендаций. Для того, чтобы подобные рекомендации были приняты к практике (не говоря уже об их реальной эффективности), необходимо специальное интервенционное исследование с дизайном case-control. Задача нашего исследования - не дать готовые рецепты по снижению уязвимости мигрантов, а обозначить характер и грани этой уязвимости для того, чтобы последующие научные и практические усилия были бы наиболее успешными.

\section{ЛИТЕРАТУРА}

Агаджанян В., Н. Зотова (2011). Социальная уязвимость и сексуальные риски женщинмигрантов из Средней Азии в Москве // Демоскоп Weekly. №465-466. URL: http://demoscope.ru/weekly/2011/0465/analit02.php\#_FNR_1 (дата обращения: 01.11.2014).

Демоскоп Weekly (2009). Мигранты и ВИЧ // Демоскоп Weekly. №387-388. URL: http://demoscope.ru/weekly/2009/0387/reprod01.php (дата обращения: 01.11.2014). 
ФМС (Федеральная Миграционная Служба) (2014). Сведения в отношении иностранных граждан, находящихся на территории Российской Федерации, в половозрастном разрезе (по состоянию на 2.10.2014 г.). URL:

http://www.fms.gov.ru/about/statistics/data/details/54891 (дата обращения: 01.11.2014).

Agadjanian V., C. Arnaldo, B. Cau (2011). Health costs of wealth gains: Labor migration and perceptions of HIV/AIDS risks in Mozambique // Social Forces. 89(4): 1097-1118.

Agadjanian V., W. Avogo (2008). Forced migration and HIV/AIDS risks in Angola // International Migration. 46(3):189-216.

Agadjanian V., N. Zotova (2012). Sampling and surveying hard-to-reach populations for demographic research: A study of female labor migrants in Moscow, Russia // Demographic Research. 26(5): 131-150.

Amirkhanian Y.A., A.V. Kuznetsova, J.A. Kelly, W.J. Difranceisco, V.B. Musatov, N.A. Avsukevich, N.A. Chaika, T.L. McAuliffe (2011). Male labor migrants in Russia: HIV risk behavior levels, contextual factors, and prevention needs // Journal of Immigrant and Minority Health. 13(5): 919-928.

Askew I., M. Berer (2003). The contribution of sexual and reproductive health services to the fight against HIV/AIDS: a review // Reproductive Health Matters. 11(22): 51-73.

Bandyopadhyay M., J. Thomas (2002). Women migrant workers' vulnerability to HIV infection in Hong Kong // AIDS Care. 14(4): 509-521.

Bravo A. (2003). Unequal access of immigrant women to reproductive health care in Madrid // Migraciones. 13: 137-183.

Brockerhoff M., A.E. Biddlecom (1999). Migration, sexual behavior and the risk of HIV in Kenya // International Migration Review. 33(4): 833-856.

Chavez L. (2012). Undocumented immigrants and their use of medical services in Orange County, California // Social Science \& Medicine. 74(6): 887-893.

Decosas J., Kane F., Anarfi J.K., Sodji K.D., H.U. Wagner (1995). Migration and AIDS // The Lancet. 346: 826-828.

Lindegren M.L., C.E. Kennedy, D. Bain-Brickley, H. Azman, A.A. Creanga, L.M. Butler, A.B. Spaulding, T. Horvath, G.E. Kennedy (2012). Integration of HIV/AIDS services with maternal, neonatal and child health, nutrition, and family planning services. The Cochrane Collaboration.

Lurie M. N. (2006). The Epidemiology of migration and HIV/AIDS in South Africa // Journal of Ethnic and Migration Studies. 32(4): 649-666.

Menjívar C., N. Zotova, V. Agadjanian (2012). The plurality of the legal context of reception: The case of Central Asian immigrant women in Russia. Presented at the American Sociological Association Annual Meeting, Denver, CO, August 17-20.

Rocheva A., V. Peshkova (2013). Reproductive behavior of women-migrants from Central Asia in Russia. Report for the Heinrich Boell Stiftung Foundation.

Schoevers M.A., M.J. Loeffen, M.E. van den Muijsenbergh, A.L. Largo-Janssen (2010). Health care utilization and problems in accessing health care of female undocumented immigrants in the Netherlands // International Journal of Public Health. 55: 421-428.

Sevoyan A., V. Agadjanian. (2010). Male migration, women left behind, and sexually transmitted diseases in Armenia // International Migration Review. 44(2): 354-375. 
UNAIDS (2012). HIV increasingly threatens women in Eastern Europe and Central Asia // URL: http://www.unaids.org/en/resources/presscentre/featurestories/ 2012/march/20120312alaskerwomeneeca/ (дата обращения: 01.11.2014).

UNAIDS (2013). Russia strengthens commitment to reversing the AIDS epidemic in the Region. URL: http://www.unaids.org/en/resources/presscentre/featurestories/ 2013/june/20130614russiaprogramme/ (дата обращения: 01.11.2014).

Wang B., X. Li, B. Stanton, X. Fang, G. Liang, H. Liu, D. Lin, H. Yang (2007). Gender differences in HIV-related perceptions, sexual risk behaviors, and history of sexually transmitted diseases among Chinese migrants visiting public sexually transmitted disease clinics // AIDS Patient Care and STDs. 21(1): 57-68.

Weine S.M., A.B. Kashuba (2012). Labor migration and HIV risk: a systematic review of the literature // AIDS \& Behavior. 16(6): 16-21.

Weine S., A. Golobof, M. Bahromov, A. Kashuba, T. Kalandarov, J. Jonbekov, S. Loue (2013). Female migrant sex workers in Moscow: Gender and power factors and HIV Risk // Women \& Health. 53(1): 56-73.

The World Bank (2014). Top Immigration Countries, 2010. URL: http://siteresources.worldbank.org/INTPROSPECTS/Resources/3349341199807908806/Top10.pdf (дата обращения: 01.11.2014).

Yang X. (2004). Temporary migration and the spread of STDs/HIV in China: Is there a link? // International Migration Review. 38 (1): 212-235.

Yang X., G. Xia (2006). Gender, migration, risky sex, and HIV infection in China // Studies in Family Planning. 37(4): 241-250.

Yang X., G. Xia (2008). Temporary migration and STD/HIV risky sexual behavior: A population-based analysis of gender differences in China // Social Problems. 55(3): 322346.

Zhussupov B., L.-A. NcNutt, L. Gilbert, A. Terlikbayeva, N. El-Bassel (2014). Migrant workers in Kazakhstan: Gender differences in HIV knowledge and sexual risk behaviors // AIDS and Behavior (online first). 


\title{
MIGRATION AND HIV RISKS: WOMEN FROM CENTRAL
}

\section{ASIA IN THE RUSSIAN FEDERATION *}

\author{
VICTOR AGADJANIAN, NATALYA ZOTOVA
}

Victor AgAdjAnian, ArIZOnA State UniVERsity. USA. E-Mail: agadjanian@asu.edu.

NATALYA ZOTOVA, INSTITUTE OF ANTHROPOLOGY AND ETHNOGRAPHY, RuSSIAN ACADEMY OF SCIENCES. RUSSIA

DATE RECEIVED: MAY 2014.

\begin{abstract}
A growing body of cross-national scholarship has been exploring the interconnections between migration and HIV infection. While often demonstrating elevated HIV risks among migrants, this scholarship has also suggested that such risks are gendered. This article uses survey and in-depth interview data to examine HIVrelated risks and attitudes among working migrant women from three Central Asian countries - Kyrgyzstan, Tajikistan, and Uzbekistan - and their native counterparts in three Russian cities. The analyses focus on exposure to risky sexual relationships, negotiation of safer sexual practices in permanent partnerships, experience of HIV testing and utilization of sexual and reproductive health care services, comparing natives and migrants as well as women of different provenance within the migrant subgroup. The results suggest that while migrant women are generally less likely to engage in risky behavior, they are also less able to negotiate safer sex within their permanent partnerships compared to native women. Migrants are also less likely to take HIV tests and to access sexual and reproductive health care. At the same time, the analyses reveal considerable variations among the three provenance groups of migrants in some of these outcomes, which call for further investigation.
\end{abstract}

Key words: migration, gender, HIV/AIDS, sexual risks.

\footnotetext{
* THIS ARTICLE WAS CARRIED OUT WITHIN THE STUDY "SEXUAL AND REPRODUCTIVE RISKS OF WOMEN MIGRANTS FROM CENTRAL ASIA IN THE CONTEXT OF HIV EPIDEMICS" SUPPORTED BY RUSSIAN FOUNDATION FOR BASIC RESEARCH AND NATIONAL INSTITUTES OF HEALTH.
}

\section{REFERENCES}

Agadjanian V., C. Arnaldo, B. Cau (2011). Health costs of wealth gains: Labor migration and perceptions of HIV/AIDS risks in Mozambique // Social Forces. 89(4): 1097-1118.

Agadjanian Victor, N. Zotova (2011). Social vulnerability and sexual risks women migrants from Central Asia in Moscow // Demoscope Weekly. №465-466. URL:

http://demoscope.ru/weekly/2011/0465/analit02.php\#_FNR_1 (accessed: 01.11.2014).

Agadjanian V., W. Avogo (2008). Forced migration and HIV/AIDS risks in Angola // International Migration. 46(3): 189-216.

Agadjanian V., N. Zotova (2012). Sampling and surveying hard-to-reach populations for demographic research: A study of female labor migrants in Moscow, Russia // Demographic Research. 26(5): 131-150.

Amirkhanian Y.A., A.V. Kuznetsova, J.A. Kelly, W.J. Difranceisco, V.B. Musatov, N.A. Avsukevich, N.A. Chaika, T.L. McAuliffe (2011). Male labor migrants in Russia: HIV risk behavior levels, contextual factors, and prevention needs // Journal of Immigrant and Minority Health. 13(5): 919-928.

Askew I., M. Berer (2003). The contribution of sexual and reproductive health services to the fight against HIV/AIDS: a review // Reproductive Health Matters. 11(22): 51-73. 
Bandyopadhyay M., J. Thomas (2002). Women migrant workers' vulnerability to HIV infection in Hong Kong // AIDS Care. 14(4): 509-521.

Bravo A. (2003). Unequal access of immigrant women to reproductive health care in Madrid // Migraciones. 13: 137-183.

Brockerhoff M., A.E. Biddlecom (1999). Migration, sexual behavior and the risk of HIV in Kenya // International Migration Review. 33(4): 833-856.

Chavez L. (2012). Undocumented immigrants and their use of medical services in Orange County, California // Social Science \& Medicine. 74(6): 887-893.

Decosas J., F. Kane, J.K. Anarfi, K.D. Sodji, H.U. Wagner (1995). Migration and AIDS // The Lancet. 346: 826-828.

Demoscope Weekly (2009). Migrants and HIV // Demoscope Weekly. № 387-388. URL: http://demoscope.ru/weekly/2009/0387/reprod01.php

Federal Migration Service (2014). Information about foreign citizens on the territory of the Russian Federation, age-sex distribution (for 2 October 2014) // URL: http://www.fms.gov.ru/about/statistics/data/details/54891

Lindegren M.L., C.E. Kennedy, D. Bain-Brickley, H. Azman, A.A. Creanga, L.M. Butler, A.B. Spaulding, T. Horvath, G.E. Kennedy (2012). Integration of HIV/AIDS services with maternal, neonatal and child health, nutrition, and family planning services. The Cochrane Collaboration.

Lurie M. N. (2006). The Epidemiology of migration and HIV/AIDS in South Africa // Journal of Ethnic and Migration Studies. 32(4): 649-666.

Menjívar C, N. Zotova, V. Agadjanian (2012). The plurality of the legal context of reception: The case of Central Asian immigrant women in Russia. Presented at the American Sociological Association Annual Meeting, Denver, CO, August 17-20.

Rocheva A., V. Peshkova (2013). Reproductive behavior of women-migrants from Central Asia in Russia. Report for the Heinrich Boell Stiftung Foundation.

Schoevers M.A., M.J. Loeffen, M.E. van den Muijsenbergh, A.L. Largo-Janssen (2010). Health care utilization and problems in accessing health care of female undocumented immigrants in the Netherlands // International Journal of Public Health. 55: 421-428.

Sevoyan A., V. Agadjanian. (2010). Male migration, women left behind, and sexually transmitted diseases in Armenia // International Migration Review. 44(2): 354-375.

UNAIDS (2012). HIV increasingly threatens women in Eastern Europe and Central Asia. URL: http://www.unaids.org/en/resources/presscentre/featurestories/2012/march/20120312alasker womeneeca/ (accessed: 01.11.2014).

UNAIDS (2013). Russia strengthens commitment to reversing the AIDS epidemic in the Region. URL: http://www.unaids.org/en/resources/presscentre/featurestories/ 2013/june/20130614russiaprogramme/ (accessed: 01.11.2014).

Wang B., X. Li, B. Stanton, X. Fang, G. Liang, H. Liu, D. Lin, H. Yang (2007). Gender differences in HIV-related perceptions, sexual risk behaviors, and history of sexually transmitted diseases among Chinese migrants visiting public sexually transmitted disease clinics // AIDS Patient Care and STDs. 21(1): 57-68.

Weine S.M., A.B. Kashuba (2012). Labor migration and HIV risk: a systematic review of the literature // AIDS \& Behavior. 16(6): 16-21. 
Weine S., A. Golobof, M. Bahromov, A. Kashuba, T. Kalandarov, J. Jonbekov, S. Loue (2013). Female migrant sex workers in Moscow: Gender and power factors and HIV Risk // Women \& Health. 53(1): 56-73.

The World Bank (2014). Top Immigration Countries, 2010. URL:

http://siteresources.worldbank.org/INTPROSPECTS/Resources/3349341199807908806/Top10.pdf (accessed: 01.11.2014).

Yang X. (2004). Temporary migration and the spread of STDs/HIV in China: Is there a link? // International Migration Review. 38 (1): 212-235.

Yang, X., G. Xia (2006). Gender, migration, risky sex, and HIV infection in China // Studies in Family Planning. 37(4): 241-250.

Yang X., G. Xia (2008). Temporary migration and STD/HIV risky sexual behavior: A population-based analysis of gender differences in China // Social Problems. 55(3): 322-346.

Zhussupov B., L.-A. NcNutt, L. Gilbert, A. Terlikbayeva, N. El-Bassel (2014). Migrant workers in Kazakhstan: Gender differences in HIV knowledge and sexual risk behaviors // AIDS and Behavior (online first). 